\title{
SMALL-SIZE DIRECT-ACTION ELECTRON ACCELERATOR WITH A HIGH-EFFICIENCY NANOSECOND PLASMA-CURRENT SWITCH
}

\author{
E.I. Skibenko, V.B. Yuferov \\ National Science Center “Kharkov Institute of Physics and Technology”, Kharkiv, Ukraine \\ E-mail: skibenko38@gmail.com
}

The paper presents the results of a study undertaken to determine operating modes for a small-size direct-action electron accelerator with a high-efficiency nanosecond plasma-current switch (PCS). The investigations have shown that using PCS as a base it is possible to develop small-size nanosecond pulsed high-current electron accelerators with a voltage pulse sharpening coefficient of about 12, beam (flow) electron energy of $300 \ldots 400 \mathrm{keV}$ and current of $100 \mathrm{kA}$ for pulse duration of $30 \mathrm{~ns}$. The ways for improving the PCS and accelerator operating parameter stability, increasing the switching current and maximum accessible switching frequency are proposed.

PACS: 621.316 .543

\section{INTRODUCTION}

Development of medium-size high-current electron accelerators (HEA) can be realized using a combination of inductive storage rings (ISR) and plasma-current switches (PCS) [1 - 10]. To perform the proposed design it is necessary to define the following: design service life of HEA and components, as well as its determining factors; pulse repetition rate and possibility of stabilizing the output device parameters (current, voltage, pulse duration); values of the voltage multiplication factor within different energy ranges and energy-to-load transfer; dynamical and integral plasma-vacuum characteristics of the discharge gap; possibility of developing a small-size pulsed accelerating installation in the transport variant with parameters: voltage of $200 \ldots 300$ $\mathrm{kV}$; current of $100 \mathrm{kA}$; pulse duration of several tens ns.

\section{EXPERIMENTAL INSTALLATION}

Experiments have been carried out on the small-size electron accelerator DI [10] equipped with a plasmacurrent switch (PCS) $[6,9]$, which is schematically represented in Fig. 1.

The accelerator is built up of a vacuum chamber having $200 \mathrm{~mm}$ diameter and $350 \mathrm{~mm}$ height comprising a system of electrodes, plasma guns and magnetic coils, pulse current generator (PCG), power supplies for plasma guns and magnetic field, trigger-pulse and timing unitnoise-protective means, diagnostic infrastructure and evacuation post.

Principal electric primary circuit parameters of the accelerator DI are: central electrode (cathode) voltage, about $50 \mathrm{kV}$; storage capacitor capacity, $3 \mathrm{mf}$; storage capacitor inductance, $40 \mathrm{nH}$; plasma current switch inductance, $122 \mathrm{nH}$; load (diode) inductance, $25 \mathrm{nH}$; plasma gun supply voltage, about $15 \mathrm{kV}$.

Discharge gap filling with plasma has been carried out using 12 planar-type plasma guns [7] (Fig. 2) uniformly spaced in the equatorial plane of the vacuum chamber (see Fig. 1).

The gun is a two-electrode coaxial system with a fluoroplastic insulator having a thickness of about $1 \mathrm{~mm}$. The discharge of the capacitor (capacity $0.25 \mu \mathrm{f}$, voltage $15 \mathrm{kV}$ ) leads to the breakdown throughout the insulator ring face and to the formation of a carbonhydrogen plasma bunch radially propagating in the direction of the central electrode-cathode.

The experiment over a long period of time demonstrated a high reliability of this-type guns. Their service life is not less than $10^{4}$ pulses. Figs. 3 and 4 present the equivalent [7] and principal [6] electric circuit of the installation under study.

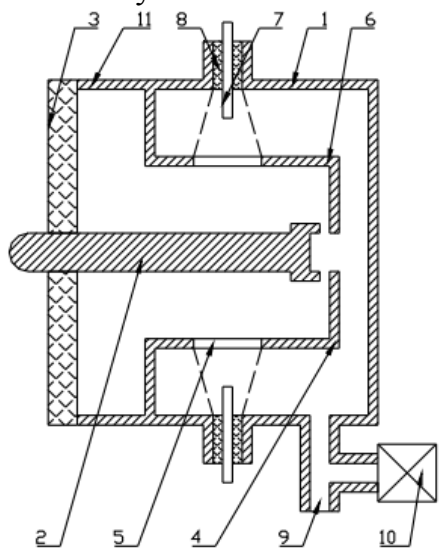

Fig. 1. Schematic view of the accelerator DI:

1 -vacuum chamber; 2 -cathode; 3 -insulator; 4 - anode; 5 -slits; 6 -diaphragm; 7 - central plasma gun electrode; 8 -plasma gun insulator; 9 - evacuation pipe; 10 -pressure gauge; 11 - seal ring

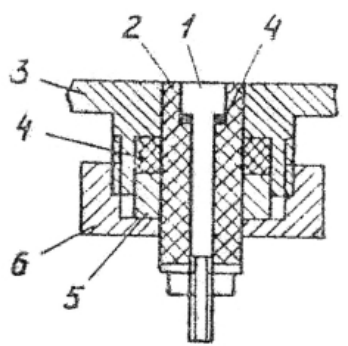

Fig. 2. Schematic view of the plasma gun: 1 -central electrode; 2 - insulator; 3 -case;

4 -vacuum seal; 5 -sleeve; 6 -screw nut

\section{METHODS AND DIAGNOSTIC TOOLS}

For the experiment the following diagnostic tools were used:

1. The current measurements were carried out with Rogowski loops (see Figs. 3 and 4): Rp - for measuring the PCG current and Rd - for measuring the accelerating diode load current;

2. The cathode voltage was determined using a calibrated capacitive divider;

3 . The measurement of the density of the plasma injected into the discharge gap using plasma guns and of the plasma space distribution was carried out with a microwave interferometers on the separate bench at a frequency of $35 \mathrm{GHz}$ (their circuits are presented in Figs. 5 and $6[6,10])$; 
4. The vacuum condition change in the period of current switching and after this was recorded with pressure pulse measuring transducers;

5. The control X-ray measurements were carried out using integral transducers with lead attenuators and scintillation transducers with photomultipliers.

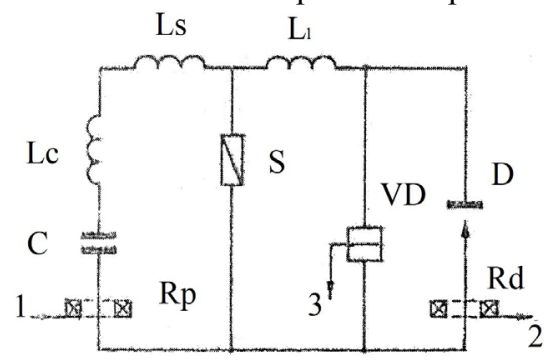

Fig. 3. Equivalent electric circuit of PCS:

$C$-storage capacitor; $L_{C}$ - storage capacitor inductance; Ls - switch inductance; $S$ - switch; $L_{l}$-load inductance; $D$-diode; VD-voltage divider; $R p$-Rogowski loope for measuring the PCG current; Rd-Rogowski loop for measuring the load current; 1, 2, 3-measuring cables

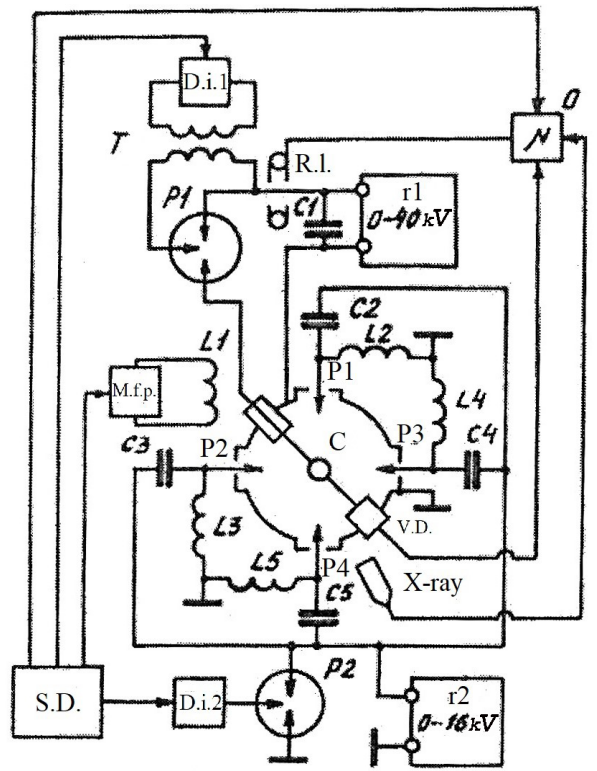

Fig. 4. Principal electric circuit: $C$-cathode; P1-P4 - plasma guns; C1-C5 - storage capacitors of PCG and plasma guns; r1-r2 - rectifiers; P1-P2 dischargers; D.i.1-D.i.2 - discharger initiation units;

$T$ - isolating transformer; L1 - external magnetic field winding; L2-L5 - high-voltage reactors; M.f.p. magnetic field power supply unit; S.D. - synchronizing device; R.l. - Rogowski loope; V.D. - voltage divider;

$X$-ray transducer; $O$-oscillograph

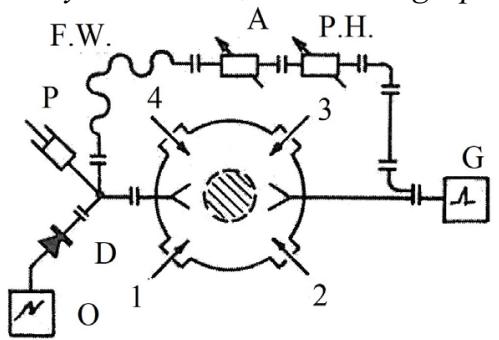

Fig. 5. Geometry and schematic of microwave probing of the plasma bunches injected from the outside into the near-cathode region: 1-4-plasma guns; G-generator; P.H. - phase shifter; A-attenuator; F.W. -flexible waveguide; $P$-plunger; $D$-detector; $O$-oscillograph

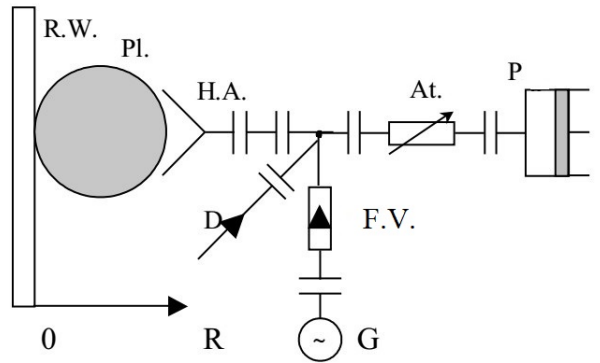

Fig. 6. Geometry and schematic of microwave probing of the plasma injected from the outside into the near-

cathode region designed to measure its transverse dimensions by the microwave reflection: $G$ - generator;

$P$-plunger; $D$-detector; H.A. - horn antenna, Pl. - plasma; R.W. - reflecting wall; At. - attenuator, F.V. - ferrite valve

\section{EXPERIMENTAL RESULTS 3.1. DYNAMIC BEHAVIOR OF THE INSTALLATION}

Measurements were carried out in two modes: operating mode using simultaneous operation of 4 or 12 plasma guns at voltage of $9.3 \mathrm{kV}$; simulation mode using gas (air, nitrogen, argon) puffing through the inlet valve.

One example of the typical pressure-time dependences in the discharge chamber is shown in Fig. 7. The leading-edge time is $0.5 \ldots 1 \mathrm{~s}$ and the vacuum regeneration time is of about 100 s. So, despite the high-speed electrical processes, the pressure is changing rather slowly. This can occur because of a heating-cooling process in any of the installation parts, e.g. electrodes.

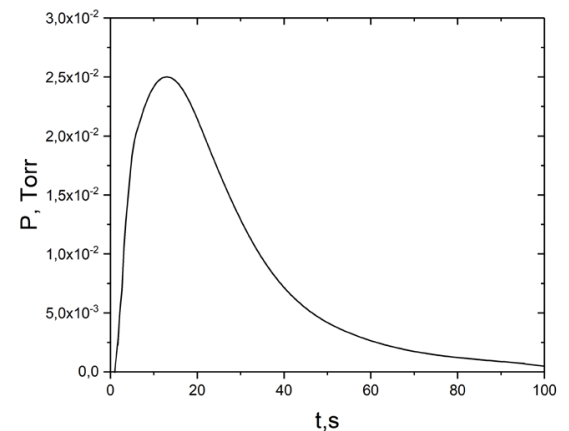

Fig. 7. Time dependence of the gaseous mixture pressure in the PCS chamber observed after the current switching event at PCG voltage of $27 \mathrm{kV}$ and evacuation rate of about $80 \mathrm{l} / \mathrm{s}$

\subsection{PLASMA, DYNAMIC AND PARAMETRIC CHARACTERISTICS OF THE INSTALLATION}

In PCS the opening switching current is determined by the density of the plasma generated by the external plasma guns. Therefore it has been very important to determine the plasma bunch parameters. Fig. 8 presents the life-time of the plasma with a critical density $N_{c r}>1.7 \cdot 10^{13} \mathrm{~cm}^{-3}$ as a function of the gun voltage.

Fig. 9 presents the time of plasma $\left(N_{c r}>1.7 \cdot 10^{13} \mathrm{~cm}^{-3}\right)$ entering into the central electrode-cathode zone (that in fact is equal to the plasma filling of the interelectrode gap) as a function of the same parameter (gun voltage) in Fig. 8. It has been established that for the plasma gun operation a so-called training is a characteristic feature. Vacuum conditions in the system are stabilized after $20 \ldots 30$ training pulses. 
Taking into account the dependences presented in Figs. 8 and 9 the time of PCG triggering relative to the plasma gun pulse was, generally, $\sim 15 \mu \mathrm{s}$.

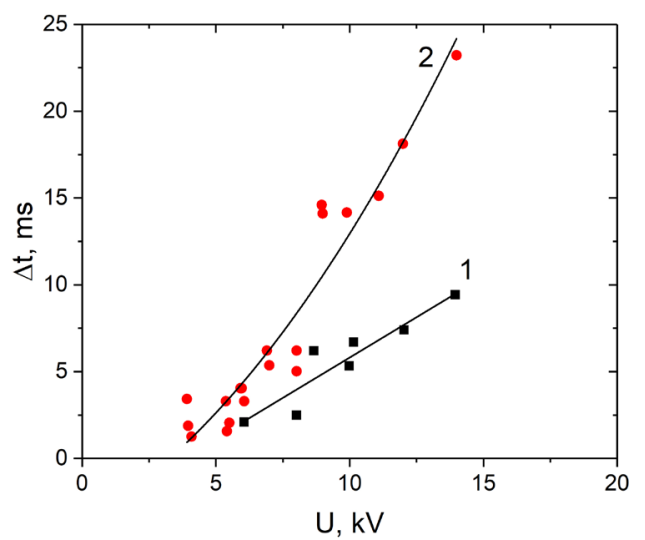

Fig. 8. Life-time of the plasma $\left(N_{c r} \geq 1.7 \cdot 10^{13} \mathrm{~cm}^{-3}\right)$ in the interelectrode gap as a function of the gun voltage: 1 - single-gun operation; 2 -four-gun operation

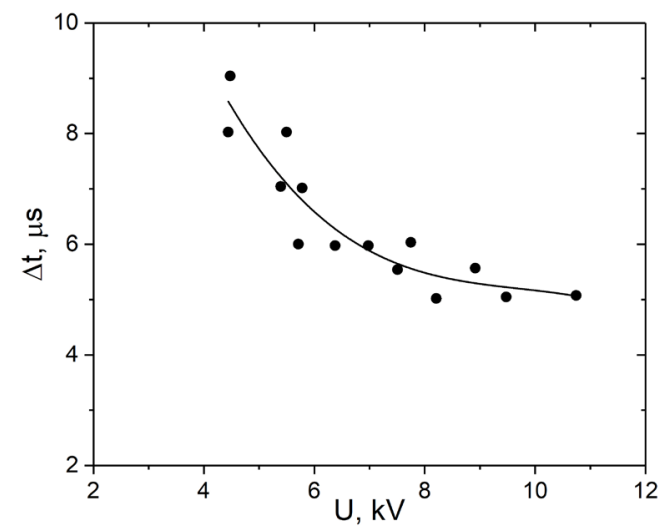

Fig. 9. The time of plasma $\left(N_{c r}>1.7 \cdot 10^{13} \mathrm{~cm}^{-3}\right)$ entering into the central electrode-cathode zone as a function of the gun voltage. Four-gun operation

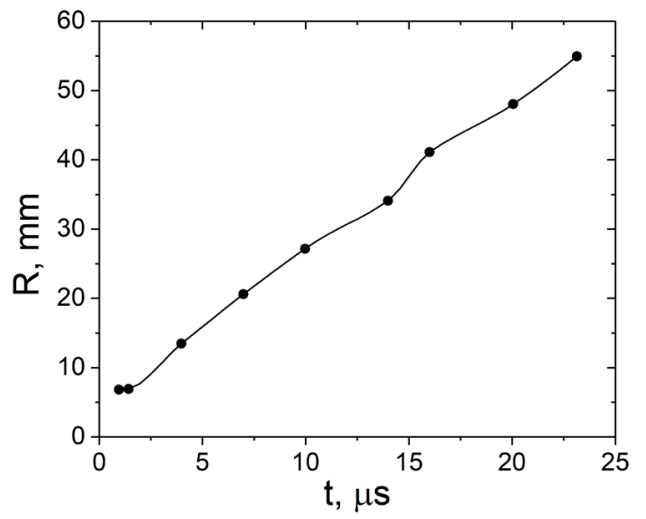

Fig. 10. Cross-section dimension (diameter) $R$ of the plasma $\left(N_{c r} \geq 1.8 \cdot 10^{13} \mathrm{~cm}^{-3}\right)$ formation (front) as a function of time

Fig. 10 presents the cross-section dimension (diameter) $\mathrm{R}$ of the plasma $\left(N_{\mathrm{cr}}>1.8 \cdot 10^{13} \mathrm{~cm}^{-3}\right)$ formation (front) as a function of time.

Using the data obtained we estimate the plasma (having a critical density) front propagation velocity in the discharge gap. From the average plasma front propagation velocity of $\sim 5 \cdot 10^{5} \mathrm{~cm} / \mathrm{s}$ we obtain the time of discharge gap filling by the plasma $\left(N_{\mathrm{cr}}>1.8 \cdot 10^{13} \mathrm{~cm}^{-3}\right)$ equal to $15 \mu \mathrm{s}$ that approximately corresponds to the experimental value of the time delay between the PCG and plasma guns triggering. This result is evidenced by the dynamics of plasma-density radial profile changing (Fig. 11) after the plasma gun pulse triggering. In Fig. 11 curve 1 is plotted for the instant of time $t=2 \ldots 4$ $\mu \mathrm{s}$; curve 2 for $\mathrm{t}=12 \mu \mathrm{s}$; curve 3 for $\mathrm{t}=20 \mu \mathrm{s}$.

The life-time of the plasma having $N_{\mathrm{cr}}>1.8 \cdot 10^{13} \mathrm{~cm}^{-3}$ is $\sim 25 \mu \mathrm{s}$ in the case of four-gun operation and $\sim 50 \mu \mathrm{s}$ with 12 guns.

Besides, the relationship $N=f(R)$ evident on the fact that the gun-injected plasma bunch is composed of two parts: a fast part with a low density $\left(N \sim 5 \cdot 10^{12} \mathrm{~cm}^{-3}\right)$ and a slow part with a density $\left(N \geq 1.8 \cdot 10^{13} \mathrm{~cm}^{-3}\right)$.

The fast low-density plasma fills the discharge gap during several $\mu$ s after plasma gun triggering and the dense plasma fills the gap during $10 \ldots 15 \mu$ s. Evidently, just the fast part of the bunch ionizes the neutral gas which fills the discharge gap and the chamber of PCS.

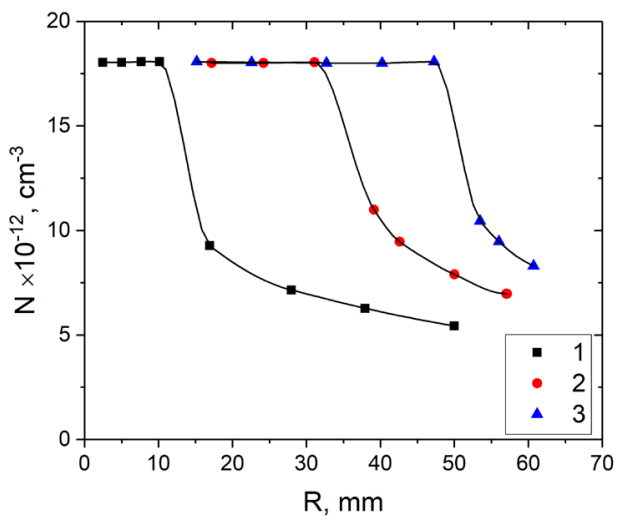

Fig. 11. Radial plasma density distribution in the discharge gap at the instant of time $t=2 \ldots 4 \mu \mathrm{s}$ after triggering the plasma gun pulses (curve 1), $t=12 \mu$ s (curve 2), $t=20 \mu$ s (curve 3 )

Fig. 12 presents the fraction of the maximum PCG current switched onto the load (electron diode) as a function of the energy content of the plasma gun power supply.

In this series of pulses a maximum PCG current value was $129 \mathrm{kA}$. The increase of a number of plasma guns (quantity of plasma) from 4 (curve 1) to 12 (curve 2 ) resulted in a significant $(25 \ldots 30 \%)$ increase of the switching current value.

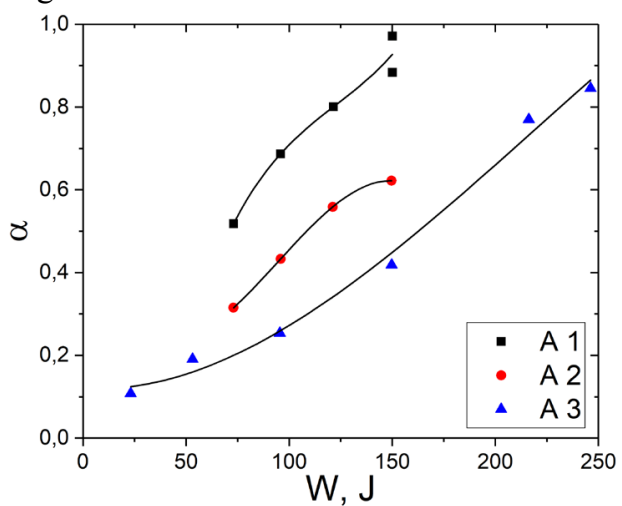

Fig. 12. Fraction of the maximum PCG current switched onto the load (electron diode) as a function of the energy content of the plasma gun power supply: A1 - 4 guns; A2 - 12 guns; A3 - Ar puffing under pressure of $1.5 \cdot 10^{-3}$ Torr 
Still more significant (by 50\%) increase of the switching current occurs after the argon puffing into the PCS chamber under pressure of $1.5 \cdot 10^{-3}$ Torr (curve 3 ). The argon presence increases the plasma density and plasma life-time due to the higher ionization cross section values in the energy range of $20 \ldots 30 \mathrm{eV}$.

Besides, the argon presence decreases the recombination rate of the primary plasma injected from the outside. A similar effect was also observed in the case of carbon-bearing atmosphere $\left(\mathrm{CO}_{2}, \mathrm{CO}, \mathrm{CH}_{4}, \mathrm{C}_{2} \mathrm{H}_{2}\right)$ in the PCS chamber.

Fig. 13 gives the results of experimental investigations on the influence of the density of neutral particles (residual gases) in the PCS chamber on the switching current value (in $\alpha$ units). It is shown that the dependence $\alpha=f\left(N_{o}\right)$ has a threshold character. The current switching begins when $N_{o}>3.5 \cdot 10^{12} \mathrm{~cm}^{-3}$. If $N_{o}>1 \cdot 10^{13} \mathrm{~cm}^{-3}$ the $\alpha$ value increases insignificantly (within $\sim 10 \%$ ).

Fig. 14 presents the maximum values of the diode voltage $U$, opening switch current $I$ and pressure increase $\Delta p[6]$ in the system after pulse triggering.

Maximum values of the voltage multiplication (sharpening) factor, in comparison with the initial one equal to $37 \mathrm{kV}$, can reach values equal to $10 \ldots 12$. The degree of exacerbation of 7.5 has $75 \%$ of the impulses out of 65 .

It has been also established that the high switching current values correspond to the lower values of the pressure (gas release) increase. Probably it is related with the change of the charge-mass composition of the plasma bunch in the cathode zone, as well as, on the total number of particles in the discharge chamber.

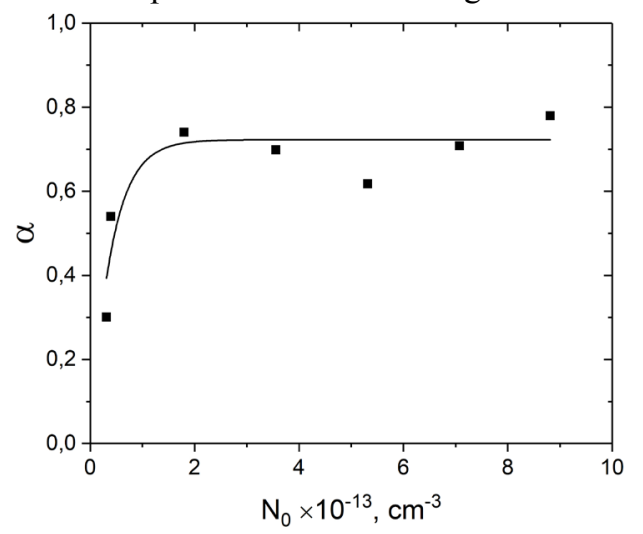

Fig. 13. Switching current value in $\alpha$ units as a function of the density of residual gases in the PCS chamber

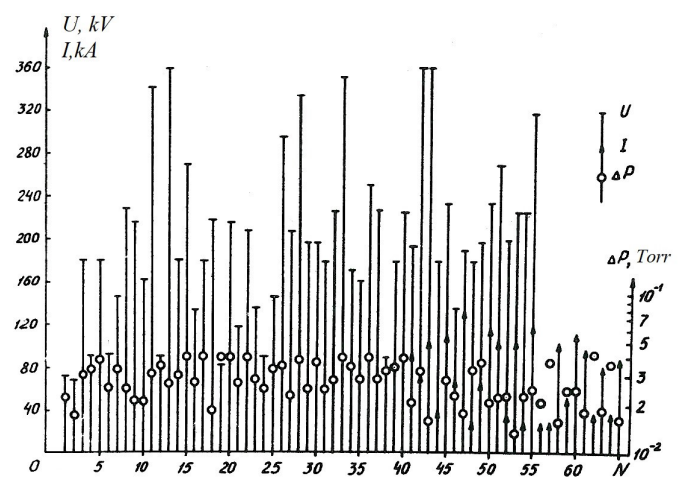

Fig. 14. Pulse-to-pulse change of the diode voltage $U$, opening switch current I and pressure increase $\Delta P$ in the system as a function of the pulse-to-pulse in the series of $N=65$
To this increase values corresponding are the single gas release values equal to $3 \mathrm{n} \cdot \mathrm{cm}^{3}$ per pulse for air, and $0.5 \ldots 1 \mathrm{n} \cdot \mathrm{cm}^{3}$ per pulse for hydrogen. Fig. 15 , shows the dependence of the multiplied diode voltage on the switching current (load current) value, generalizing the experimental results of this investigation.

In other series of experimental pulses observed were the voltage pulses with a large spread of points, but with an amplitude to $450 \mathrm{kV}$ and, correspondingly, with a multiplication factor value equal to 12 .

At the same time, as is seen from Fig. 16, the averaged energy of accelerated electrons in the diode, determined using the integral X-ray transducers, is at the level of $270 \mathrm{keV}$ with a voltage multiplication factor more than 7 that is within limits of the experimental error (see Fig. 15).

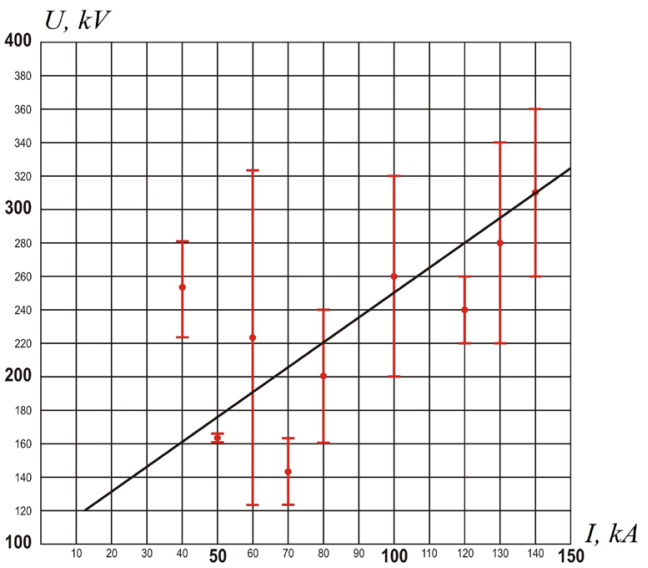

Fig. 15. Voltage-current characteristics of PCS designed for a small-size direct-action electron accelerator demonstrating the multiplied diode voltage as a function of the switching current (load current). A minimum thread of experimental points at $I_{N}=$ const is $\leq \pm 23 \%$, a maximum one is $\sim \pm 45 \%$

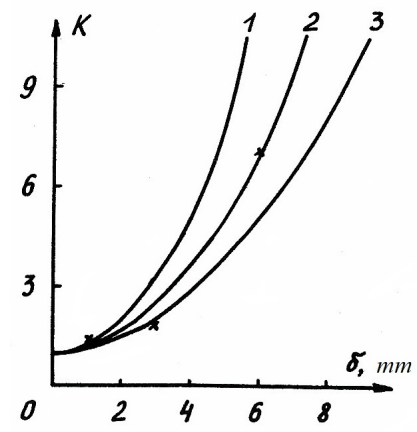

Fig. 16. Multiplicity of X-ray radiation attenuation on the lead absorbers as a function of their thickness:

1, 3 - literature data; 2 -experimental results; $1-200 \mathrm{keV} ; 2-270 \mathrm{keV} ; 3-300 \mathrm{keV}$

\section{CONCLUSIONS}

1. Investigations have shown that on the base of a plasma current switch (PCS) with an inductive storage rings (ISR) [1 - 10] it is possible to develop small-size pulsed high-intensity electron accelerators operating in the nanosecond range with voltage pulse sharpening coefficients of 12 , beam (flux) electron energy of $300 \ldots 400 \mathrm{keV}$, current of $100 \mathrm{kA}$ and pulse duration of $30 \mathrm{~ns}$.

2. Small-size and transportability factor of the accelerator DI is demonstrated by its overall sizes 
$(180 \times 120 \times 60 \mathrm{~cm})$ and by the possibility to compose its total mass step-by-step from the following components:

- vacuum chamber with accessories - $15 \mathrm{~kg}, \mathrm{PCG}$ 200(140) kg;

- plasma gun power supply -46(2) kg;

- magnet field power supply - 12(3) kg;

- triggering and timing units $-1 \mathrm{~kg}$;

- noise-protecting and diagnostic equipment - $4 \mathrm{~kg}$;

- evacuation post - $15 \mathrm{~kg}$;

- measuring equipment $-10 \mathrm{~kg}$;

- mounting frame $-12 \mathrm{~kg}$.

The total weight equals to $315 \mathrm{~kg}$ and so the accelerator DI is an easy- transported facility.

A change-over to the pulsed voltage transducer allows one to decrease significantly the weight of power supply devices (see figures in brackets) and, finally, the total weight of the accelerating installation to $200 \mathrm{~kg}$ $(>30 \%)$.

3. The operating parameter stability of PCS and accelerator in whole (current, voltage) is improved by increasing the quantity and density of plasma in the discharge gap, as well as, by reaching a more uniform plasma density distribution along the gap.

4. The switching current value is increased either by increasing the quantity and density of plasma or due to the external (internal) injection of inert gas, e.g. argon, into the PCS chamber before the current switching event.

5. Maximum attainable frequency of current switching can be reached by increasing the rate of evacuation of the PCS chamber, by decreasing the internal gas release value and by using the PCS operation under higher maximum pressure, e.g. $10^{-3}$ Torr instead of $10^{-4}$ Torr that reduces the time of evacuation of the accelerator chamber after the PCS triggering pulse.

\section{REFERENCES}

1. P.F. Ottinger, S.A. Goldstein, R.A. Meger. Theoretical modeling of the plasma erosion opening switch for inductive storage application // J. Appl. Phys. 1984, v. 56, p. 774.
2. B.M. Kovalchuk, G.A. Mesyats. High-intensity power nanosecond pulse generator with a vacuum line and plasma opening switch // DAN USSR. 1985, v. 284, № 4, p. 857 (in Russian).

3. D.D. Hinshelwood, J.R. Boller, R.J. Comisso, et al. Long conduction time plasma erosion opening switch experiment // Appl. Phys. Lett. 1986, v. 49, № 24, p. 1635 .

4. E.G. Krastelev, A.G. Mozgovoj, M.Yu. Solovyov. Experimental investigation of a plasma erosion opening switch: Preprint № 326. M.: FIAN USSR, 1987 (in Russian).

5. Hidenory Matsurawa, Netsyda Akitsu. Highpressure operation of a beam // J. Appl. Phys. 1988, v. 63 (9), p. 4392.

6. V.G. Artyukh, E.I. Skibenko, Yu.V. Tkach, Yu.B. Yuferov. Investigation of a high-current plasma switch: Preprint KIPT 89-28. Kharkiv: NSC KIPT, 1989, p. 12.

7. V.G. Artyukh, E.I. Skibenko, Yu.V. Tkach, Yu.B. Yuferov. Investigation of a high-current plasma switch: Preprint KIPT 94-12. Kharkiv: NSC KIPT, 1989, p. 9.

8. V.G. Artyukh, E.I. Skibenko, Yu.V. Tkach, Yu.B. Yuferov. Investigation of a possibility for stabilizing the characteristics of a high-speed current switch // Ukrainskyj Fizychnyj Zhurnal. 1995, v. 40, № 8, p. 805-806 (in Ukrainian).

9. V. Yuferov, E. Skibenko, I. Onishchenko, V. Artyuch and O. Druy. Investigation of high current plasma opening switch at low gas pressure // Digest of Technical Papers. 12th IEEE International Pulsed Power Conference. v. 2. (Cat. № 99CH36358), Monterey, CA, 1999, p. 1215-1217.

10. E.I. Skibenko, Yu.B. Yuferov. V.G. Artyukh. Smallsized electron accelerator DI with a highperformance plasma opening current switch // Problems of Atomic Science and Technology. Series “Plasma Physics”. 1999, № 3, p. 236-238.

Article received 09.02.2018

\section{МАЛОГАБАРИТНЫЙ УСКОРИТЕЛЬ ЭЛЕКТРОНОВ ПРЯМОГО ДЕЙСТВИЯ С ЭФФЕКТИВНЫМ ПЛАЗМЕННЫМ КОММУТАТОРОМ ТОКА НАНОСЕКУНДНОГО ДИАПАЗОНА Е.И. СКибенко, В.Б. Юферов}

Представлены результаты исследований режимов работы малогабаритного ускорителя электронов прямого действия с эффективным плазменным коммутатором тока (ПКТ) наносекундного диапазона. Показано, что на базе ПКТ возможно создание малогабаритных импульсных сильноточных электронных ускорителей наносекундного диапазона с коэффициентами обострения импульса напряжения до 12, энергией электронов пучка (потока) 300...400 кэВ и током 100 кА при длительности импульса 30 нс. Предложены пути для повышения стабильности рабочих параметров ПКТ и ускорителя в целом, увеличения значения коммутируемого тока, а также пути увеличения предельно достижимой частоты коммутаций.

\section{МАЛОГАБАРИТНИЙ ПРИСКОРЮВАЧ ЕЛЕКТРОНІВ ПРЯМОЇ ДІЇ $З$ ЕФЕКТИВНИМ ПЛАЗМОВИМ КОМУТАТОРОМ СТРУМУ НАНОСЕКУНДНОГО ДІАПАЗОНУ \\ С.І. Скібенко, В.Б. Юферов}

Представлені результати досліджень режимів роботи малогабаритного прискорювача електронів прямої дії з ефективним плазмовим комутатором струму (ПКС) наносекундного діапазону. Показано, що на основі ПКС можливе створення малогабаритних імпульсних сильнострумових електронних прискорювачів наносекундного діапазону $з$ коефіцієнтами загострення імпульсу напруги до величини, що дорівнює 12, енергією електронів пучка (потоку) $300 \ldots 400$ кеВ і струмом $\approx 100$ кА на протязі 30 нс. Запропоновані шляхи для підвищення стабільності робочих параметрів ПКС і прискорювача в цілому, збільшення величини струму комутації, а також шляхи зростання величини гранично можливої частоти комутацій. 